\title{
Antitrust Laws in the European Economic Community: A Sequel
}

\author{
Stefan A. Riesenfeld*
}

$\mathrm{O}^{\mathrm{n}}$ URS IS AN AGE of rapid change. This holds true not only in the realm of technology but also in the fields of social and economic institutions. As a result it is distressing but not surprising that my recent discussion of antitrust laws in the European Economic Community ${ }^{\mathfrak{1}}$ is in need of supplementation giving information about further important developments so soon after its publication.

\section{DEVELOPMENTS ON THE SUPRANATIONAL LEVEL}

It was reported in the previous discussion ${ }^{2}$ that the issuance of Regulation No. 17 of the Council of Ministers ${ }^{3}$ constituted the commencement of a new phase in the emerging supranational antitrust law of the European Economic Community. That event was soon followed by the enactment of a special regulation of the Council of Ministers "governing the application of certain rules of competition to the production of and commerce in agricultural products" 4 and of a regulation of the Commission for the application of Regulation No. 17.5 Regulation No. 17, as pointed out before, ${ }^{6}$ subjects restrictive agreements, decisions, and concerted practices prohibited by article 85(1) of the Treaty Establishing the European Economic Community, ${ }^{7}$ with the exception of certain enumerated categories, ${ }^{8}$ to the onus of timely notification in order to benefit from the immunity accorded by article 85 (3) of the treaty or of certain purging possibilities introduced by the regulation itself ${ }^{9}$ even the exempted classes had to be notified to the Commission prior to a later date in order to invoke the purging provi-

* Emanuel S. Heller Professor of Law, University of California School of Law, Berkeley.

1 Riesenfeld, Antitrust Laws in the European Economic Community, 50 Carrr. L. Rev. 459 (1962).

2 Ibid.

3 Regulation No. 17, 5 Journal OfFiciex des Communautés Européennes [hereinafter cited as J.O.E.C.] 204 (1962).

4 Regulation No. 26, 5 id. at 993.

5 Regulation No. 27, 5 id. at 1118.

6 Regulation No. 17 arts. 4-7; see Riesenfeld, supra note 1, at 462-63.

7298 U.N.T.S. 11 (1958).

8 For the classes of restrictive measures that are exempt from the onus of early notification by Regulation No. 17 art. 4(2), see Riesenfeld, supra note 1, at 463; CCH CoMsmoN MKT. Rep. $\llbracket 2431$ (1962).

${ }^{9}$ Regulation No. 17 arts. 4-7(1). 
sions. ${ }^{10}$ The original deadline for notification of the pre-existing nonprivileged restrictive arrangements was August 1, 1962.

This date subsequently proved to be too early in view of the complicated decisions to be made by the affected enterprises. Therefore, the Council of Ministers, by Regulation No. 59,11 replaced it with two subsequent dates: November 1,1962 , and February 1, 1963. The earlier date was applicable to pre-existing restrictive agreements, resolutions, or concerted practices, proscribed by article 85 (1) of the EEC Treaty and not exempted by Regulation No. 17, article $4(2)$, for which the participating enterprises if numbering three or more, wished either to seek a declaration of the nonapplicability of article $85(3)$ (declaration of harmlessness) ${ }^{12}$ or to invoke the purging provisions. The later date was reserved for such arrangements if only two enterprises engaged therein.

Of course, the scope, effect, and apparent gaps of the involved and obscure Regulation No.17, which represented a compromise between sharply conflicting national approaches, ${ }^{13}$ as well as its implication for the interpretation and application of article $85(1)$ and (3) of the EEC Treaty prompted a veritable flood of discussions, commentaries, speculations, and controversies. ${ }^{14}$ As the regulation makes timely notification a prerequisite

10 Regulation No. 17 art. 7(2); see Riesenfeld, supra note 1 , at 464.

115 J.O.E.C. 1655 (1962).

12 Riesenfeld, supra note 1 , at 462 .

13 See especially Armengaud, La thèse française en matière d'entente, 1962 REvuE DU MarchE் Common 84; Fracheschelli, Le premier règlement d'application des articles 85 et 86 du Traité de Rome, id. at 345 ; Françon, Les ententes et les monopoles selon le Traité de Rome, 89 JouRnal dU DRoIT INTERnationaI 368 (1962).

14 See especially Campbell, Regulations as to the Implementation of Articles 85 and 86 of the Rome Treaty, 11 INT'L \& CoMp. L.Q. 1027 (1962); Deringer, Die erste Durchfïhrungsverordnung zu den Artikeln 85 und 86 des EWG-Vertrages, 12 WIRTSCHAFT UND WETTBEWERB [hereinafter cited as WuW] 81 (1962); Deringer, Inhalt und Auswirkungen der ersten Kartellverordnung der europäischen Wirtschaftsgemeinschaft, 6 GEWERBLICHER RECHTSSCHUTZ UND URHEBERRECHT, AUSLANDS-UNd INTERNATHONAIER TEII 273 (1962); Deringer, Les règles concernant la concurrence dans le cadre du marché commun entrent en vigueur, 1962 REVUE DU MARCHÉ CoMmun 70; Fracheschelli, supra note 13; Françon, supra note 13; Hellman \& Pfeiffer, Alleinvertriebsverträge im System des europäischen Kartellrechtes, 8 AUSSENWIRTSCHAFTsDIENST DES BETRIEBS-BERATERS 241 (1962); Knopp, Uber die Anwendbarkeit von Artikel 85 des EWG-Vertrages auf Individualverträge, 8 id. at 269 ; Obernolte, Die erste Durch führungsverordnung zu den Artikeln 85 und 86 des EWG-Vertrages, 8 WETTBEWERB IN RECAT uND Praxis 103 (1962); Précigout, La sanction des infractions aux règlements de la C.E.E., 1962 Revue dU MARCaÉ CoMMUN 142; Samkalden, De Bevoegdheidsverdeling in de eerste kartelverordening van de E.E.G. (pts. 1-2), 10 SociaAl Economische WETGEving 205, 273 (1962); Samkalden, Parlementaire verantwoordelijkheid voor de inhoud van de eerste Europese kartelverordening, 10 id. at 108; Schepers, De toepassing van art. 85 E.E.G. op industrijle overeenkomsten, 10 id. at 453; Schumacher, Die Dutrchführung der Artikel 85 und 86 des RomVertrages, 12 WuW 475 (1962); Seward, Antitrust Law Problems of American Business in Dealing with Common Market Countries, 18 Bus. Law. 775 (1962); Snijders, De kartelverordening van de Europese Economische Gemeenschap (pts. 1-2), [1962] NEDERLANDS JURIS- 
for securing important privileges, the extent of that onus has been of special concern to the enterprises affected. To assist them in their efforts to comply with the new regime the Commission prepared a Practical Guide, the definitive version of which was released for distribution in September $1962 .{ }^{15}$

The reasons for the final form given to Regulation No. 17, as well as the future application of article 85(3) of the EEC Treaty and of the regulation, have been the subject of a series of written parliamentary questions and important replies thereto by the Commission..$^{16} \mathrm{~A}$ number of them concerned the effect of a certificate of "negative clearance" and the legal status of: (a) bipartite exclusive dealing arrangements, and (b) restrictive clauses in transfers or licenses of industrial property rights. The Commission made it clear ${ }^{27}$ that the dispensation from the burden of early filing provided for the categories of restrictive measures specified in article 4(2) was limited to bipartite resale price maintenance agreements which do not contain additional restrictive clauses, and that the exemption did not apply in any way to bipartite exclusive dealing arrangements. The Commission pointed out further that the latter type, if susceptible of an adverse effect on inter-1nember state commerce, was subject to the prohibition of article 85 (1) of the treaty, unless sanctioned by a declaration under article 85(3) subsequent to timely notification, i.e., notification prior to February 1, 1963.

On November 9, 1962, the Commission published four "communications" proposing its future course of action with respect to certain categories of exclusive dealing agreements and patent licenses and soliciting comments thereto. ${ }^{18}$ In two of these communications ${ }^{19}$ the Commission specified the conditions under which certain types of exclusive dealing arrangements and patent licenses would be deemed not to be outlawed by article 85 (1) of the treaty; in the other two the Commission enumerated three categories of exclusive territorial marketing arrangements and three types of engagements in patent licenses for which it would issue, effective for three years after the publication in the official gazette, a generic declara-

TENBLAD 442, 476, and the follow-ups-Alexander, De E.E.G.-kartelverordening, id. at 587, and Snijders, De E.E.G.-kartelverordening, id. at 646; Van Hecke \& Suetens, Le premier règlement européen sur les cartels et les monopoles, 77 JoURNAL des TRIBUNAUX 361 (1962); Wolf, Zum Kartellrecht der E.W.G, 12 WuW 645 (1962).

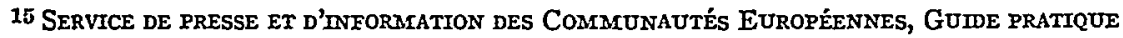

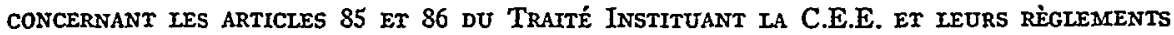
D'APPLICATION (1962).

16 See especially Questions Nos. 96 (posed in 1961, answered in 1962), 32, 59, 61, 71, 95, and replies thereto, 5 J.O.E.C. 1218, 1593, 2134, 2135, 2417, 2617 (1962).

17 Especially in its replies to Questions No. 71 and 95, id. at 2417, 2617.

185 J.O.E.C. 2627 (1962); corrections of Nov. 13, 1962, id. at 2687.

19 Second Communication Relating to the Application of Art. 85 of the Treaty to Certain Exclusive Marketing Agreements, and Second Commumication Relating to the Application of Art. 85 of the Treaty to Certain Patent Licenses, id. at 2628, 2629. 
tion under article $85(3)$ of the inapplicability of the prohibitions of article 85 (1), provided that a number of carefully defined negative conditions are complied with.

On December 20, 1962, the Commission, in the light of the observations received, determined the action to be taken. ${ }^{10 a}$ It modified its position in the four communications in several respects. First of all, it resolved to refrain from issuing the proposed generic declarations under article 85(3) as to certain exclusive dealing agreements and patent licenses, considering the time not yet ripe for such a step. Vice versa, it adhered to its idea of publishing two announcements specifying types of exclusive dealing contracts and patent licenses that, in its opinion, do not fall under article 85 (1). In the case of exclusive dealing arrangements, only exclusive territorial distributorships of commercial representatives (as distinguished from merchants operating in their own names) are regarded as nonrestrictive. With respect to patent licenses, a number of limitations of the licensee as to manufacture, sale, or use of the patented invention and certain other duties or restrictions imposed upon him are deemed to be not reached by article $85(1)$, because either they are considered immanent in the patent right or no stifling of competition is seen therein. Likewise listed as being outside that prohibition are ties of the licensor in the form of sole or exclusive licenses. In addition, the Commission amended Regulation No. 27 by providing a simplified notification for exclusive supply or procurement contracts between not more than two firms.

As indicated before, the effect of the regulations on the national antitrust laws and the resolution of conceivable conflicts between the supranational regime and the national orders is a much debated problem. ${ }^{20} \mathrm{It}$ has been suggested recently by the director-general, Mr. Verloren van Themaat, that the practical significance of that problem might be exaggerated and that, at any rate, the Council, with a qualified majority, may adopt a regulation which attributes overriding effect to the supranational law and the action of the Commission thereunder within the ambit of inter-member state commerce. ${ }^{21}$

19a The action is published in 5 J.O.E.C. - (Dec. 24, 1962), in the form of a regulation (Regulation No. 153) and two announcements of the Commission.

20 See especially Deringer, Die erste Durchfültrungsverordnung zu den Artikeln 85 und 86 des EWG-Vertrages, 12 WuW 81, 89 (1962); Samkalden, De Bevoegdheidsverdeling in de eerste kartelverordening van de E.E.G. (pts. 1-2), 10 Sociaal Economische Wetceving 205, 273 (1962); important also, though written prior to the issuance of Regulation No. 17, are: Clèment, La délimitation des compétences respectives de la Commission du Marché Commun et des autorités nationales en matière de cartels, in 1 KARTELLE UND MONOPOLE DS MODERNEN RECHT 377 (1961); Schwartz, Anwendbarkeit nationalen Kartellrechts auf internationale Wettbewerbsbeschränkungen, in 2 id. at 673; Steindorff, Das Wettbewerbsrecht der europäischen Gemeinschaftcn und das nationale Recht, in 1 id. at 157.

21 Van Themaat, Probleme der Rechtsangleichung im Gemeinsamen Markt, 17 BETRIEDS-

BERATER 1131, 1132 (1962). 
Certainly, Regulation No. 17 has already produced noteworthy repercussions in the national sphere. Thus, the German Court of Appeals of Berlin (Kammergericht) reversed, inter alia, on the basis of Regulation No. 17, a decision of the appellate board of the German Federal Cartel Office that denied effectiveness to a rebate cartel of German windowpane manufacturers which provided for a rebate measured by purchases from cartel members. ${ }^{22}$ The Cartel Office took the position that exclusion of purchases from manufacturers in the other Community countries might be a violation of article 85(1) of the EEC Treaty. The court of appeals held that at the time of the administrative action the cartel members could still notify the cartel to the Brussels Commission and request a declaration under article 85(3). As a result, a violation of article 85(1) of the EEC Treaty could not be invoked as the basis for an objection under sections 3(4) and 12(1)(1) of the German Law Against Restraints of Competition. ${ }^{23}$

In addition, the Brussels Commission made a demarche to the French government to remind it of the provisions of Regulation No. 17, article $9(3)$, which requires the national authorities to refrain from applying article $85(1)$ of the treaty when and so long as a proceeding before the Commission is pending. That step was prompted by the action of the Commercial Tribunal of the Seine which refused to stay proceedings involving the legal protection in France of exclusive distributorships granted to French firms by German manufacturers. ${ }^{24}$

II

DEVELOPMENTS ON THE NATIONAL LEVEL

\section{A. France}

Undoubtedly the most important event in the development of French antitrust law occurring after completion of the manuscript of the prior report was the decision of the French Court of Cassation (criminal chamber) in the matter of Nicolas, Société Brandt et Société Photo Radio Club ${ }^{25}$

22 Judgment of May 4, 1962, Kammergericht (Berlin Court of Appeals), 12 WuW 697 (1962) (Windowpane Manufacturers case).

23 Under $\S 3(4)$, in conjunction with $\S 12(1)(1)$, rebate cartels are exempted from the generic prohibition against cartels, provided that the stipulated rebates are not discriminatory and that the cartel does not entail abuses of market power gained through the statutory privilege. See Riesenfeld, The Protection of Competition, in 2 AMrerican ENTERPRISE IN THE European Comsmon Martet: A Legal Profine 197, 218 (1960).

24 See the account of the incident given in the report of Councillor Costa to the French Court of Cassation in the case of Nicolas, Soc. Brandt et Soc. Photo Radio Club, [1962] RECEUIL DALLOZ [hereinafter cited as D.] Jurisprudence 497, discussed in text accompanying note 32 infra.

25 Cour de Cassation (Ch. crim.), July 11, 1962, [1962] D. Jurisprudence 497, [1962] Juris Ciasseur Péryodique [hereinafter cited as J.C.P.] II. 12799. 
which reversed in part the judgment of the Court of Appeals of Paris. ${ }^{20}$ The decision concerned the validity of exclusive territorial distributorships under French law which had been denied by the court below as being in contravention of the "refusal to sell" prohibition contained in article 37(1) (a) of the Price Ordinance No. 45-1483. ${ }^{27}$ The judgment of the court below, as well as that of the Court of Cassation, attracted enormous attention, even abroad, ${ }^{28}$ in view of the fact that many foreign manufacturers maintain such arrangements in France. As has been pointed out previously, the famous interpretative circular of the General Directorate for Prices and Economic Investigations of March 31, 1960 (named, after its author, the Fontanet circular), took the position that exclusive dealerships might be outside the statutory prohibition against a refusal to sell provided they meet certain standards, among them strict mutuality. ${ }^{29}$ The holding of the Court of Appeals of Paris, consequently, came as a great surprise and shock and it was expected that it would be reversed by the Court of Cassation, especially in view of some prior dicta by that body. The Court of Cassation, indeed, took the anticipated action. In its opinion the court pointed out that the statutory prohibition against a refusal to sell is qualified by a number of conditions, namely, that the requested sale be within the limits of the seller's supplies and under conditions conforming to commercial usages, and that the demand be made bona fide. ${ }^{30}$ It held that a refusal to sell based on an exclusive dealership agreement may, under specified circumstances, come within the envisaged exceptions and that the trial judge must make a finding to the effect that such justification is not present. The court stated specifically:

[A]n exclusive dealership agreement by which the contracting parties have reciprocally limited their commercial freedom (if it is established that it has neither the purpose nor the effect, even indirectly, of limiting the freedom of the dealer to determine himself as he sees fit the resale price of the article and that, on the contrary, it tends essentially to assure an improvement of the service to the consumer) may have the effect of rendering the merchandise vis-à-vis third parties as not being legally within the limits of the seller's supplies, [and] ... such a practice, in the commerce of articles requiring a great technical skill or of goods of high quality, may constitute a commercial custom within the meaning of article $37(1)(a) .^{31}$

26 The decision of the court of appeals is discussed in Riesenfeld, supra note 1, at 470 .

27 For details see Riesenfeid, supra note 1, at 466-67.

28 See Cosnard, Concession exclusive et refus de vente, [1962] D. Chronique 40; Holl, Vertragsfreiheit und "refus de vente," 8 WetTBEWERB IN RECHT uTd PRAXIS 156 (1962); Mezger, Das Verbot von vertikalen Bindungen, Diskriminierungen und Lieferverweigerungen und seine Wirkung auf Exklitsivverträge in Frankreich, 8 AUSSENWIRTSCHAFTSDIENST DES BETRIEBS-BERATERS 216 (1962); Safferling, Kartellrecht in Frankreich, 12 WuW 661 (1962). 29 See Riesenfeld, supro note 1, at 469-70.

30 For the text of the statute see Riesenfeld, The Legal Protection of Competition in France, 48 CALIF. L. REv. 574, 593 (1960).

31 [1962] D. Jurisprudence at 501, [1962] J.C.P. II. at 12788. (Emphasis added.) 
The court remanded the case for redetermination to another court of appeals, but sustained the judgment below to the extent that it rejected a demand for damages by the party whose order was refused on the ground that such claims could not be asserted in criminal proceedings involving economic infractions.

The detailed report of a member of the court, Mr. Councillor Costa, which preceded the decision by the panel, deserves particular attention. ${ }^{32}$ The judge emphasized that the proper construction of the law necessitated an examination of the social and economic consequences which would be produced by a strict or liberal interpretation of the prohibition. He submitted the argument that a liberal approach might be preferred, particularly upon consideration of the repercussions which a strict view would have on the competitive position of French manufacturers vis-à-vis other Common Market enterprises. He pointed out that the position of the court of appeals precluded French manufacturers from entering into arrangements which foreign manufacturers could maintain with impunity even in France and that, in any event, the decision of the extent to which exclusive local distributorships affecting inter-member state commerce are or are not sanctionable under article $85(3)$ of the EEC Treaty were to be determined exclusively by the Brussels authorities in conjunction with the national experts. This exegesis shows clearly that the national courts are well aware of the emergence of a paramount supranational system governing the control of anticompetitive practices.

In addition, three decisions of the Court of Appeals of Paris should be noted. In one of them ${ }^{33}$ it was held that a publisher was guilty of a refusal to sell because he intentionally failed to supply two consumers' cooperatives with books ordered at the prices and under the conditions of payment ordinarily conceded to bookstores. The defendant tried to invoke an exclusive dealing agreement concluded subsequent to the refusal to sell, but the court rejected that defense. In the second case ${ }^{34}$ the court held that a German manufacturer who had granted a French firm an exclusive distributorship of his products in France for an indefinite period could denounce the agreement at any time, but that he committed a tort by hiring away the French firm's key personnel before the expiration of the relation. The last case $^{35}$ concerned a restrictive agreement of the horizontal type. One cartel partner sued the other for specific performance. The defendant pleaded

32 The report is published in [1962] D. Jurisprudence 497.

33 Judgment of June 28, 1961, Cour d'Appel de Paris, [1962] J.C.P. II. 12475.

34 Soc. Rheinstahl Hanomag v. Soc. S.E.M.A., Cour d'Appel de Paris, Feb. 14, 1962, [1962] D. Jurisprudence 514 .

35 Glacières et Frigorifiques de l'Alimentation v. Glacières et Frigorifiques de Fécamp, Cour d'Appel de Paris, May 4, 1961, [1962] J.C.P. II. 12517. 
the illegality of the contract under article 59 bis of the Price Ordinance, which outlaws horizontal restraints of competition. ${ }^{36}$ The court accepted the defense and refused to examine whether the cartel was sanctioned by the savings clauses of article $59 \mathrm{ter}$, since plaintiff had failed to obtain a declaration to that effect from the Commission Technique des Ententes. The decision has met with strong criticism by the commentators and is in conflict with a prior holding of another appellate court. ${ }^{37}$

\section{B. Germany}

In Germany, the federal government prepared a report concerning needed amendments to the Law Against Restraints of Competition of July $27,1957,{ }^{38}$ transmitting it to the German parliament on August 22, $1962 .^{30}$ The report was accompanied by an affirmative advisory opinion rendered by the Advisory Council to the Federal Ministry of Economics. The report recommended, inter alia, (1) a repeal of the existing exemptions for resale price maintenance agreements covering publications or trademarked articles that are in competition with similar goods, provided such agreements are properly notified and not abusive; (2) an increase of the presently existing powers of the Cartel Authority, ${ }^{40}$ with respect to the suppression of exclusive dealing arrangements that unfairly limit outsiders in their freedom to compete; and (3) an extension of the supervision of enterprises with dominant market power. These recommendations have, of course, been widely noted and commented upon in the technical journals. ${ }^{41}$

The provision of the German Law Against Restraints of Competition which predicates the legality of resale maintenance agreements for trademarked articles on the "existence of price competition with articles of equal nature produced or sold by others" ${ }^{42}$ formed the subject of an interesting adjudication of the Berlin Court of Appeals, which has jurisdiction to review decisions of the Federal Cartel Office. ${ }^{43}$ The articles in question were automobile tires. The court considered cross-elasticity the basic criterion

36 See Riesenfeld, supra note 1 , at 468.

37 Augé v. Etabl. Dorian-Holtzer, Jackson et Cie, et autres, Cour d'Appel de Lyon, June 13, 1960, [1961] D. Jurisprudence 148, discussed in Riesenfeld, supra note 1, at 470.

38 [1957] I Bundesgesetzblatt 1081. [Hereinafter cited as Restraints of Competition Law].

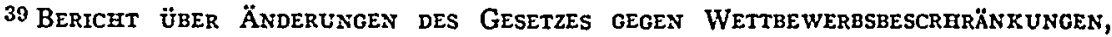
Deutscher Bundestag, Drucksache IV/617 4 Wahlperiode (1962).

40 The Cartel Authority comprises federal and state agencies. See Riesenfeld, supra note 23 , at 229.

41 See, e.g., Zur Reform des Gesetzes gegen Wettbeu'erbsbeschränkungen, 17 BETRIE口SBERATER 979 (1962).

42 Restraints of Competition Law § $16(1)$; see Riesenfeld, supra note 23, at 222.

43 Judgment of March 20, 1962, Kammergericht (Berlin Court of Appeals), 12 WuW 689 (1962), 8 Wettbewerb in Recht und Praxis 237 (1962) (The Automobile Tire Resale Price Maintenance case). 
for equal nature. Price competition was held to be operative if the market structure prevents an arbitrary price level, despite the fact that price uniformity exists for the sanie type of products of different manufacturers.

Another noteworthy decision of the same court concerned the legality of the rebate cartel of the German windowpane nuanufacturers. ${ }^{44}$ The Federal Cartel Office objected to the permissibility and validity of the cartel agreentent primarily on the ground that the oligopolistic structure of the windowpane market excluded the possibility of competition with respect to price, quality, contract terms, or service and left rebates the only open field of competition. The court of appeals found that the structure of the market precluded competition even with respect to discounts based on quantity or storage time which formed the subject of the agreement. It concluded, therefore, that the cartel would not constitute a misuse of a market position gained by an exemption from the general prohibition against cartels and, accordingly, reversed the decree of the Cartel Office. The conceivable conflict with article 85(1) of the Rome Treaty was held to be immaterial in view of the fact that the cartel might still secure immunity under article $85(3)$ of the treaty. ${ }^{45}$

The prohibition of discrimination against other enterprises which section 26(2) of the German Law Against Restraints of Competition imposes upon enterprises with dominant market power, cartels, and enterprises engaging in retail price maintenance ${ }^{46}$ has been the subject of interesting decisions by the Supreme Court and the lower courts. ${ }^{47}$ Without going into detail, it may be pointed out that the application of this provision has involved the courts in discussions of market delimitation and functional differences similar to those found in American antitrust cases. Violation of the antidiscrimination section has been held to entitle the victim to damages. ${ }^{48}$

44 See note 22 supra and accompanying text.

45 See the discussion of this point in text accompanying notes 22-23 supra.

46 See Riesenfeld, supra note 1 , at 474.

47 See, e.g., Judgment of Aug. 10, 1960, Bundesgerichthof [hereinafter cited as B.G.H.], 14 NEUE JURISTISCHE WOCHENSCHRIFT [hereinafter cited as N.J.W.] 172 (1961) (exclusion from membership in milk producers' cooperative); Judgment of Oct. 26, 1961, B.G.H., 36 Entscheidungen des Bundesgerichthofes in Zivilsachen [hereinafter cited as B.G.H.Z.] 91, 12 WUW 284 (1962) (refusal of social insurance entity to deal with manufacturer of therapeutical rubher stockings) ; Judgment of March 8, 1962, B.G.H., 37 B.G.H.Z. 30, 15 N.J.W. 1105 (1962) (refusal of producer of chocolates to supply "cash and carry" wholesaler) ; Judgment of May 24, 1962, B.G.H., 15 N.J.W. 1567 (1962) (selective permission of use of trademark to manufacturers of replacement parts); Judgment of Nov. 17, 1960, District Court of Mannheim, 12 WoW 143 (1962) (establishment by manufacturer of minimum quantity of annual purchases as prerequisite for direct supply of dealers).

48 See the decision of the B.G.H. in the rubber stockings case, supra note 47 . Conversely, a purported violation of $\$ 26(2)$ cannot be invoked to justify disregard of a manufacturer's distribution system by a wholesaler who is excluded from supply by the manufacturer because the wholesaler operates on a cash and carry basis. Judgment of March 8, 1962, B.G.H., supra note 47 . 


\section{Italy}

Italy is the major member of the European Economic Community that has not yet enacted general legislation for the protection of competition. Efforts to adopt provisions of that nature have been made in parliament since 1950 , but up to now none of them have come to fruition. ${ }^{40}$ Late in 1959, the government, under the leadership of the Hon. Colombo, Minister for Industry and Commerce, prepared a draft which was to a large extent modeled on the pertinent articles in the EEC Treaty. ${ }^{50}$ It was transmitted to the National Council for Economic and Labor Matters for criticism and advice on December 7, 1959. The Council responded with an opinion which suggested a number of modifications, but was, in general, somewhat undecided in view of the controversies about the relation between national legislation and the EEC Treaty and the regulations to be issued thereunder. ${ }^{51}$ After receipt of this opinion the Ministry released an explanatory report. ${ }^{62}$ At the same period five competing antitrust bills were introduced by members of the parliament. ${ }^{53}$ As a consequence of this diversified drive for the passage of a national statute for the supervision and regulation of anticompetitive practices, the Italian parliament in April 1961 appointed a parliamentary commission of inquiry to examine the Italian problems derived from the limitations placed on competition in the economic field. ${ }^{54}$ The commission was to submit its report in the spring of 1962 . No discussion of its findings has as yet come to the attention of this writer.

With respect to case law, it may be noted that the Italian courts have persisted in their position that third parties are not bound to respect exclusive territorial distributorships. ${ }^{55}$

\section{The Netherlands}

During 1961 and 1962 the highest court of the Netherlands, the Hoge

40 See Riesenfeld, supra note 23 , at 289.

50 For a summary see Riesenfeld, $i d$. at 290; the text is reprinted in [1960] Foro Italiano [hereinafter cited as F.I.] IV. 29, and 9 Rivista DI DiRitro INDUSTRIale [hereinafter cited as R.D.IND.] I. 98 (1960). For a discussion see Fracheschelli, Osservazioni sommarie sul disegno di legge per la tutela della liberiè della concorrenza del Sig. Ministro Colombo, 9 R.D.IND. I. 104 (1960).

51 The opinion of the C.N.E.L. is reprinted in [1961] F.I. IV. 122, and 9 R.D.IND. I. 114 (1960).

52 The report is reprinted in 9 R.D.IND. I. 127 (1960).

53 The competing bills are reproduced in 8 R.D.IND. I. 189, 200 (1959), and 9 id. I. at 296, 301, 311 (1960).

54 For details see [1961] F.I. IV. 130; 10 R.D.IND. I. 294 (1961).

55 In addition to the authorities cited by Riesenfeld, supra note 23 , at 289 , see Leon, Contributo allo studio della questione se siano libere le importazioni in zona di eschusiva, 10 R.D.IND. I. 168 (1961); Troller, Unlaulerer Wettbewerb, begangen durch Ausbeutung fremder Leistung, 9 R.D.InD. I. 72, 81 (1960). 
Raad, handed down a series of decisions that have been heralded ${ }^{56}$ as a limitation upon, or retreat from, its former position which seemingly accorded distributors of trademarked articles with exclusive territorial dealerships an unqualified protection in tort against disregard of their franchises by outsiders. $^{57}$ The first indication of a reorientation was the decision in K.I.M. v. Sieverding. ${ }^{58}$ Plaintiff Sieverding was the exclusive distributor in the Netherlands of articles manufactured by the Grundig Works in Germany. Defendant K.I.M., a Dutch firm, marketed Grundig-manufactured articles in the Netherlands which had been sold to it by an unidentified German dealer in violation of an export prohibition stipulated between Grundig and that German firm. The Hoge Raad, reversing the court below, held that Sieverding had no cause of action against K.I.M. for the reason that defendant owed plaintiff no duty to respect its monopolistic position and to refrain from selling articles supplied by a German firm, which in turn was under no obligation to plaintiff not to deal with K.I.M.

This new trend was further manifested by a subsequent holding in the case of Nibeja v. Grundig Radio-Werks, G.m.b.H. ${ }^{59}$ In that litigation the manufacturer himself sought an injunction against a Dutch firm which had resold articles produced by plaintiff in disregard of the exclusive dealership for the Netherlands of another firm. The court denied relief on the ground that purchase and resale of articles by an outsider with the knowledge that the manufacturer had obligated his customers to observe certain restrictions was in itself not tortious against the manufacturer. The court pointed out specifically that a tort might be committed under particular conditions, especially if the outsider uses the breach of contract by one of the dealers to place other members of the distributive organization at a competitive disadvantage. The court, however, failed to find allegations to that effect in the complaint.

Conversely, in the latest decision in that series, the judgment in Holst v. Philips, ${ }^{60}$ the Hoge Raad upheld, with an insignificant qualification, an order of the court below which enjoined defendant, who was not a "recognized" retailer of plaintiff's articles, from interfering with plaintiff's marketing organization by procuring such articles in violation of plaintiff's contractual distribution arrangement and reselling them below plain-

${ }^{6}$ See Mok, Een nieuze fase in de "Kolynos"-jurisprudentie, 10 Socraal Economische WETGEVING 466 (1962).

57 The older approach is known as the Kolynos doctrine, named after a case decided by the Hoge Raad, Nov. 11, 1937, [1937] Nederlandse Jurisprudentie [hereinafter cited as N.J.] No. 1096.

58Hoge Raad, Jan. 13, 1961, [1962] N.J. No. 245, [1961] NederLANDS JURISTENBLAd [hereinafter cited as N.J.B.] 49.

50 Hoge Raad, Jan. 12, 1962, [1962] N.J. No. 246, [1962] N.J.B. 62 .

60 Hoge Raad, April 27, 1962, [1962] N.J. No. 259. 
tiff's prescribed retail prices. As a result the nuances which transform conduct from lawful competition into a tort vis-à-vis the manufacturer and his distributive organization are not completely settled and await further judicial clarification.

To the same class of adjudications belongs the complex chain of decisions in the controversy of Bosch E van Rijn v. de Geus ${ }^{61}$ which led to the celebrated decision of the European Court of Justice, mentioned before. ${ }^{62}$ The case originated as an action for damages and an injunction brought by a German manufacturer and its Dutch exclusive distributor against a Dutch invader of the reserved territory. The trial court held that defendant's conduct constituted an actionable tort vis-à-vis both plaintiffs and justified the relief prayed for, but refused to grant an immediate injunction prior to the finality of the judgment. ${ }^{63}$ Defendant appealed and plaintiffs applied for a summary issuance of a temporary injunction. The presiding judge granted the relief and defendant appealed from that order. The appellate court reversed the order of the presiding judge on the ground that defendant was under no obligation vis-à-vis the exclusive dealer to refrain from selling articles of the kind in question and that the alleged injury to the manufacturer, if actionable, was not severe enough to justify the issuance of a temporary injunction. ${ }^{64}$ Subsequently, in conjunction with the appeal on the merits, the appellate court made an order to submit certified questions as to the effect of the EEC Treaty to the European Court of Justice. ${ }^{65}$ The Hoge Raad, on petition for review of this order, upheld the same. ${ }^{60}$ Accordingly, it is clear that the appellate court, in rejecting the existence of an actionable wrong to the exclusive dealer, followed the new trend.

A further noteworthy case in that category of controversies is the decree of the presiding judge of the tribunal of 's-Gravenhage rendered in injunction proceedings instituted by Graetz, N.V. ${ }^{67}$ Plaintiff was the Dutch assignee of a trademark originally owned by Graetz-K.G., the German

61 Judgment of Oct. 26, 1960, Tribunal of Rotterdam, [1961] N.J. No.159; Judgment of April 7, 1961, Court of Appeals of 's-Gravenhage, [1961] N.J. No. 204; Order of June 30, 1961, Court of Appeals of 's-Gravenhage, [1961] N.J. No. 375 (request for interpretation by EEC Court of Justice); Judgment of May 18, 1962, Hoge Raad, [1962] N.J.B. 463.

02 Riesenfeld, Antitrust Laws in the European Economic Conmunity, 50 CaLIF. L. Rev. 459,462 (1962).

63 Judgment of Oct. 26, 1960, Tribunal of Rotterdam, [1961] N.J. No. 159.

64 Judgment of April 7, 1961, Court of Appeals of 's-Gravenhage, [1961] N.J. No. 204.

65 Order of June 30, 1961, Court of Appeals of 's-Gravenhage, [1961] N.J. No. 375.

${ }^{66}$ Judgment of May 18, 1962, Hoge Raad, [1962] N.J.B. 463.

6i Decree of Nov. 24, 1961, Tribunal of 's-Gravenhage, 10 SoctaAd Economiscire WETGEVING 58 (1962); German translation in 6 Gewerblicirer ReChtssCHUTZ UND URIEBERRECHT, Auslands-Und Internationaler TeIL 311 (1962). 
general distributor of products manufactured by the German Graetz-A.G. Plaintiff maintained and supplied a network of authorized retailers who were parties subject to retail price maintenance agreements. Defendant, who was not one of these dealers, procured equipment with the Graetz trademark and sold it below the prescribed price. The requested relief was denied on the ground that the arrangement between Graetz-K.G. and Graetz, N.V., as well as the retail price maintenance scheme, violated the principles of the EEC Treaty and the Dutch law which must be interpreted in that spirit.

Finally, it should be mentioned that the Dutch government submitted to the Dutch parliament an interesting account of the enforcement of the Economic Competition Act during the calendar year $1961 .^{68}$ The Minister of Economics reported, inter alia, that on the basis of a careful factual investigation he had reached the conclusion that it was inadvisable to issue a generic invalidation of retail price maintenance and exclusive dealing agreements rather than to proceed on a case-by-case basis.

\section{E. Belgium}

In a much commented upon decision, the Belgian Court of Cassation, on June 17,1960 , held that the contractual concession of an exclusive national distributorship does not give the privileged enterprise an absolute right vis-à-vis third parties to have his franchise respected, but that it is entitled to damages or injunctive relief only if particular additional circumstances are present, such as complicity of the defendant in a breach of contract or other faulty, unfair, or unprofessional conduct on his part. ${ }^{69} \mathrm{De}$ spite its latitude, the decision settled to a certain extent a conflict of long standing among the lower courts. ${ }^{70}$ The Court of Cassation reiterated its holding in a decision of November 3,1961, with the minute addition to the effect that the blameworthiness which justifies relief must not consist merely in the disregard of the franchise. ${ }^{71}$ The decision was preceded by sig-

68 Documents of the Staten-Generax, Verslag over de toepassing van de Wet ecoNOMISCHE MEDEDINGING VAN 1 JANUARI 1961 TOT 1 JANUARI 1962, 2d Chamber, Sess. 1961-1962, Doc. No. 6689 I. (1962). See also Ellis, Das niederländische Kartellgesetz und seine Durchführung, 8 AUSSENWIRTSCHAFTSDIENST DES BETRIEBS-BERATERS 273 (1962).

69 Dick et Snoeck v. Holvoet, Cour de Cassation, June 17, 1960, [1960] Pasicrisie Belge I. 1191, 75 Journar des Tribunaux [hercinafter cited as J.T.] 627 (1960) (note Brunnen); see comments by Limpens \& Van Damme, Les Obligations, 14 Revue CrITIQUe de JURISPRUdence BELGE [hereinafter cited as R.C.J.] 337, 381 (1960).

$70 \mathrm{Cf}$. Riesenfeld, Protection of Competition, in 2 American ENTERprise IN THE European Common Market: A Leoar Profile 197, 272-73 (1960).

71 Thienpont v. S.P.R.L. "Codaco," Cour de Cassation, Nov. 3, 1961, [1962] Pasicrisie Belge I. 252, 76 J.T. 737 (1961). 
nificant conclusions of the advocate general, Mr. Dumon. The recent decisions of the lower courts reflect the reorientation. ${ }^{72}$

Evidently, the validity of exclusive agreements inter partes remains unaffected by this case law and, in fact, is recognized implicitly by a recent statute of July 27,1961 , regulating their termination. ${ }^{73}$ The effect, however, of article 85(1) and (3) of the EEC Treaty upon the status of such agreements remains to be settled.,

\section{CONCLUSION}

The foregoing analysis shows that the legal order of competition in the European Common Market is in the process of a swift and profound realignment. As in the United States, ${ }^{74}$ the most difficult problem of all is that of tracing the tenuous line which separates legitimate marketing arrangements from proscribed restraints. Apparently, current political pressures are such that many practices which rigidify the market structure and stabilize economic power will pass unchallenged and be condoned as reasonable and salutary.

72 In Dick et Snoeck v. Holvoet, supra note 69, the Court of Appeals of Brussels, on remand, dismissed the complaint, Feb. 28, 1961, 76 J.T. 370 (1961). In S.A. Labor. Cochard v. Soc. Coop. Pharmacie du Treurenberg, Commerce Tribunal of Brussels, Dec. 16, 1961, 77 J.T. 264 (1962), the court applied the same principles to resale price maintenance contracts and dismissed an action against a cooperative which had bought pharmaceutical products from a dealer who had not observed his obligations. But cf. Aspa v. Superbazars, Presiding Judge of the Commerce Tribunal of Brussels, March 23, 1962, 77 J.T. 298 (1962), 16 R.C.J. 326 (1962) (with extensive note by Waelbroeck), in which it was found that defendant was guilty of complicity.

73 [1962] Moniteur Belge 7518, discussed by de Hautevinte, Le Statut des concession-

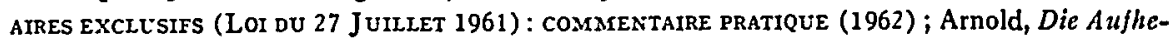
bung von Alleinverkaufsrechten nach belgischem Recht, 3 AUSSENWIRTSCHAFTSDIENST DES Betriebs-Beraters 67 (1962); Sarre, Exclusive Agency Agreements, 1962 J. Bus. L. 400.

${ }^{4} 4$ See Riesenfeld, Vertikale I'ettbewerbsbeschränkungen: Neuere Strömungen im amerikanischen Antitrust-Recht, 11 WuW 813 (1961). 